\title{
Adverse Events and Risk Factors Associated with Chloral Hydrate Sedation for Brain Magnetic Resonance Imaging in the Neonatal Intensive Care Unit
}

\author{
Byeong Sub Park ${ }^{1}$, Yeong Myong Yoo ${ }^{1}, \mathrm{O}_{\text {Kyu } \mathrm{Noh}^{2,3}}$, Moon Sung Park ${ }^{1}$, and Jang Hoon Lee ${ }^{1}$ \\ Departments of ${ }^{1}$ Pediatrics, ${ }^{2}$ Radiation Oncology, ${ }^{3}$ Biomedical Informatics, Ajou University Hospital, Ajou University School of Medi- \\ cine, Suwon, Korea
}

\section{ABSTRACT}

Purpose: This study investigated the incidence of adverse events (AEs) and risk factors associated with sedation using chloral hydrate $(\mathrm{CH})$ for brain magnetic resonance imaging (MRI) in the neonatal intensive care unit (NICU).

Methods: This was a retrospective study of infants who received $\mathrm{CH}$ for brain MRI in the NICU. Among the enrolled infants $(n=143), 12.6 \%(n=18)$ were included in the AE group and $87.4 \%(\mathrm{n}=125)$ were in the non-adverse event group (NAE)

Results: Gestational age (GA) at birth and corrected GA at sedation were $35^{+0} \pm 7^{+2}$ and $39^{+5} \pm 3^{+1}$ respectively. The rate of AEs was $12.6 \%$, included oxygen desaturation (5.6\%), aspiration $(4.9 \%)$, paradoxical agitation $(0.7 \%)$, tachycardia or bradycardia $(0.7 \%)$, and arrest $(0.7 \%)$. In univariate analysis, the AE group was younger in corrected GA at sedation than the NAE group $\left(37^{+2}\right.$ [range, $36^{+0}$ to $40^{+0}$ ] vs. $40^{+1}$ [range, $38^{+2}$ to $41^{+4}$ ], $P=$ 0.015). There was no significant difference in $\mathrm{CH}$ dosage ( 50.0 [range, 50.0 to 50.0 ] vs. 50.0 [range, 50.0 to 50.0 ], $P=0.092$ ), cardiopulmonary ( $33.3 \%$ [n=6] vs. $17.6 \%[\mathrm{n}=22$ ], $P=0.209)$ and central nervous system $(61.1 \%$ [n=11] vs. $65.6 \%[\mathrm{n}=82], P=0.054)$ morbidity. In multivariate analysis, $\mathrm{CH}$ dosage was the only significant risk factor for AEs associated with sedation (odds ratio, 1.04; 95\% confidence interval, 1.01 to $1.07 ; P=$ 0.0186).

Conclusion: AEs associated with sedation using $\mathrm{CH}$ are not uncommon and should be considered when using high dose $\mathrm{CH}$ for diagnostic testing in the NICU.

Key Words: Chloral hydrate; Infant, newborn; Adverse effects

\section{서론}

재태 연령 37 주 미만의 미숙아 출생이 증가하고 ${ }^{1)}$ 신경 발달 이상의 고위험군인 미숙아의 생 존율이 향상됨에 따라 신생아집중치료실 퇴원 후 성장 과정에서 발생 가능한 운동, 인지, 정서적 문제 등 신경 발달 예후 평가에 대한 중요성이 강조되고 있다 ${ }^{2,3}$. 신생아 뇌 발달을 확인할 수 있 는 검사 중 뇌 자기공명영상은 촬영 시간이 긴 단점이 있으나 조직 간의 대비와 민감도가 높은 장
Received: 14 September 2018

Revised: 3 November 2018

Accepted: 15 January 2019

Correspondence to: Jang Hoon Lee Department of Pediatrics, Ajou University Hospital, Ajou University School of Medicine, 164 World cup-ro, Yeong. tong-gu, Suwon, 16499, Korea

Tel: +82-31-219-5167

Fax: +82-31-219-5169

E-mail: neopedlee@gmail.com https://orcid.org/0000-0003-4765-9948

Copyright(c)

By Korean Society of Neonatology.

All right reserved.

This is an Open-Access article distributed under the terms of the Creative Commons Attribution Non-Commercial License (http://creativecommons.org/licenses/ by-nc/4.0), which permits unrestricted non-commercial use, distribution, and reproduction in any medium, provided the original work is properly cited. 
점이 있어 뇌 초음파보다 구조와 이상을 확인하는 데 유리하여 대뇌 피질의 이상, 이소증 그리고 후두와의 이상 등의 기형 및 뇌 발달 확 인에 유용하게 사용된다 ${ }^{4,5)}$. 따라서 신생아, 특히 극소저체중출생아 나 미숙아의 신경계 합병증 진단의 높은 중요성으로 뇌 초음파의 보 완적 검사로 뇌 자기공명영상 촬영이 증가하고 있다 ${ }^{6,7)}$.

뇌 자기공명영상 촬영은 촬영 시간이 상대적으로 길고 움직임에 의한 영상의 질 저하가 발생하여 신생아에서는 전처치로 진정이 필 요하다 ${ }^{8)}$. 신생아의 진정 치료에 사용되는 약물은 일반적으로 경구 chloral hydrate (CH), 정맥 내 미다졸람(midazolam) 등이 있으며") 그 중 정맥 내 미다졸람은 호흡억제 등의 위험성이 보다 높아 경구 $\mathrm{CH}$ 를 통한 진정 치료가 경제적 및 진료 환경적인 영향을 고려하였 을 때 일차적 투여 약물로 널리 사용되고 있다. 이러한 이유로 신생 아의 경구 $\mathrm{CH}$ 진정 치료가 빈번하게 시행되나 이를 통해 발생 가능 한 신생아에서의 이상 반응에 대한 직접적인 연구가 많지 않다 ${ }^{8,10,11}$.

이에 신생아집중치료실에서 뇌 자기공명영상 촬영을 위한 경구 $\mathrm{CH}$ 를 통한 진정 치료의 이상 반응 및 이상 반응 발생에 영향을 미칠 수 있는 위험인자를 확인하기 위하여 본 연구를 시행하였다.

\section{대상 및 방법}

\section{1. 연구 대상}

본 연구는 2013년 1월부터 2016년 12월까지 본원 신생아집중치료 실에 입원하여 $\mathrm{CH}$ 진정 치료 후 뇌 자기공명영상 촬영을 시행하였 던 143 명을 대상으로 의무기록 조사를 통해 후향적으로 진행하였으 며, 그 중 이상 반응이 있었던 집단을 연구군, 이상 반응이 없었던 집 단을 대조군으로 선정하여 진행하였다. 연구 진행은 아주대학교병 원 기관연구윤리심의위원회(IRB No. AJIRB-MED-MDB-18-340)의 승인을 받았다.

\section{2. 진정 치료 지침}

신생아의 진정 치료 시행 전 5\% 포도당 수액과 같은 멸균 수액 식 이 시 2 시간, 모유, 분유 수유 시 4 시간의 금식을 시행하며 ${ }^{12)}$ 정해진 금식시간이 지켜진 환아에서 $\mathrm{CH}$ (포크랄시럽 $100 \mathrm{mg} / \mathrm{mL}, \mathrm{Hanlim}$, Seoul, Korea)를 검사 시행 30 분 전 경구로 $50 \mathrm{mg} / \mathrm{kg}$ 투여하며, 적절 한 깊이의 진정이 되지 않으면 30 분 후 $25-50 \mathrm{mg} / \mathrm{kg}$ 을 경구로 한 차 례 더 투여하여 총 $100 \mathrm{mg} / \mathrm{kg}$ 까지 투여한다 ${ }^{9,10,13,14)}$.

\section{3. 자료 수집 방법}

각 대상의 진정 치료 방법, 이상 반응 발생의 여부, 이전의 병력 및 상태 등은 본원의 전자의무기록을 통하여 수집하였다. 진정 치료 시 행 중에 발생한 이상 반응 및 상태 변화는 진정 치료 시행 동안 동행 한 의사가 신체 진찰 및 휴대용 모니터를 통하여 직접 환아의 상태를
확인 후 심박수, 호흡수, 말초 산소포화도, 진정 깊이 등 진정 처치 및 기록 지침에 따른 항목을 기록한 진정기록지 내용을 통하여 수집 하였다. 또한 진정 치료가 끝난 후 발생한 이상 반응 및 상태 변화는 진정 치료 후 최소 24 시간 동안 신생아집중치료실 입원 기간 지속적 으로 유지되는 생체징후 모니터에 의한 감시와 지속적인 신체 진찰 을 통한 담당 주치의가 작성한 경과기록지, 해당 환아의 담당 간호사 에 의해 기록된 간호기록 및 임상관찰 기록을 통하여 확인하였다.

\section{4. 이상 반응의 종류 및 위험요소의 분류}

이상 반응의 종류로 모순 흥분은 진정 치료 후 오히려 진정 깊이가 낮아지거나 진정이 이루어지지 않으면서 과도한 울음 및 심박수가 증가한 경우, 산소포화도의 감소는 진정 치료 시행 전 산소 투여 없 이 말초 산소포화도 유지가 되었으나 진정 치료 시행 후 말초 산소포 화도가 $90 \%$ 미만으로 감소한 경우, 심박수의 이상 변화는 진정 깊이 가 깊어지면서 보채는 증상이 없으나 심박수가 180 회/분 이상으로 증가하거나 말초 산소포화도의 감소 없이 심박수가 80 회/분 미만으 로의 감소하는 경우로 구분하였다. 또한 위 자극에 의한 흡인은 진 정 치료 시행 이전 수유 시 말초 산소포화도 감소나 흡인, 역류 등의 문제가 없었으나 진정 치료 시행 후 24 시간 이내에 수유 후 발생하는 반복적인 말초 산소포화도 감소로 산소투여가 필요한 경우, 그리고 심폐소생술이 필요한 저산소증 및 심박수 감소(arrest)는 말초 산소 포화도가 $90 \%$ 미만으로 감소하며 심박수가 60 회/분 미만으로의 감 소로 구분하여 조사하였다 ${ }^{8,11,15)}$. 산소포화도의 감소, 심박수의 변화, 모순적 흥분, 그리고 심폐소생술이 필요한 저산소증을 동반한 심박 수 감소는 $\mathrm{CH}$ 투여 1 시간 이내에 발생한 급성기 이상 반응이었고, 역류증상은 $\mathrm{CH}$ 투여 1 시간 이후, 24 시간 이내에 발생한 지연기 이상 반응이었다.

진정 치료 후 이상 반응 발생률에 영향을 미칠 수 있을 것으로 추 정되는 위험인자로는 출생 시 재태 연령 및 진정 치료 시행 시 교정 재태 연령, 심폐기능에 영향을 미칠 수 있는 상태 및 질환(심폐계의 문제), 중추신경계의 문제로 나누어 조사하였다. 심폐계의 문제에는 치료가 필요했던 동맥관개존, 기관지폐형성이상, 진정 치료 시행 당 시 산소 의존 여부 그리고 무증상 동맥관개존, 무증상 심방중격결손 과 난원공개존증 등을 제외한 선천성심질환으로 구분하였으며 중 추신경계의 문제에는 뇌기형, 경막외 출혈, 경막하 출혈 등을 포함 한 두개강내출혈, 3-4단계의 뇌실내출혈, 뇌수막염과 경련 및 신생 아가사로 구분하였다. 신생아가사의 진단은 출생 후 측정한 5 분, 10 분 아프가점수가 모두 5 점 미만이며 동맥혈 가스분석 검사 결과 $\mathrm{pH}$ 7.00 미만 또는 염기결핍 $12 \mathrm{mmol} / \mathrm{L}$ 이상 혹은 모두 있는 경우, 저산 소성 허혈성 뇌병증이 동반된 다발성 장기부전이 있는 경우 진단하 였다 ${ }^{16,17)}$. 


\section{5. 통계}

수집된 정보들은 중간값(25-75 percentile), 수(\%)로 표기하였 으며 통계분석은 R 통계(R foundation for Statistical Computing, Vienna, Austria) 프로그램을 이용하여 시행하였다. 각 집단 간의 비 교는 Student $t$-test 또는 Kruskal-Wallis rank sum test로 연속변수를 분석하였고 chi-square test 또는 Fisher's exact test로 명목변수를 분 석하였다. $P$ 값 0.05 미만인 경우 통계적으로 유의미한 것으로 정의 하였으며 $P$ 값 0.1 미만인 인자들을 대상으로 다변량분석을 시행하 였다.

\section{결과}

본 연구에 포함된 신생아들의 출생 시 재태 연령은 평균 $35^{+0}$ 주 였으며 검사 시행 당시의 교정연령은 평균 $39^{+4}$ 주였다. 전체 환아 중 28명(19.6\%)에서 뇌 자기공명 촬영 당시에 심폐계의 문제가 있 었으며 기관지폐형성이상 8 명(5.6\%), 선천성심질환 2 명(1.4\%), 산 소 의존 11 명(7.7\%), 치료가 필요했던 동맥관개존 7명(4.9\%)이었 다. 89 명(62.2\%)의 환아에서 중추신경계의 문제가 있었으며 뇌기 형 5명(3.5\%), 두개강내출혈 8명(5.6\%),3-4단계의 뇌실내출혈 22명 (15.4\%), 뇌수막염 11 명(7.7\%), 경련 및 신생아가사 43명(30.1\%)이 었다(Table 1). 중추신경계의 문제가 없었던 환아는 출생 체중 1,500 $\mathrm{g}$ 미만 또는 재태 연령 $28^{+0}$ 주 미만이었던 환아를 대상으로 검사 목 적으로 진행하였던 경우이다.

Table 1. Baseline Characteristics of Enrolled Infants

\begin{tabular}{lc}
\hline Characteristic & No. $(\%)$ \\
\hline Total & 143 \\
$\mathrm{GA}\left(\mathrm{wk}^{+\mathrm{d}}\right)$ & $35^{+0}$ \\
Corrected age $\left(\mathrm{wk}^{+\mathrm{d}}\right)$ & $39^{+4}$ \\
Morbidities associated with CPS & $28(19.6)$ \\
BPD & $8(5.6)$ \\
CHD & $2(1.4)$ \\
Oxygen dependency & $11(7.7)$ \\
PDA & $7(4.9)$ \\
Morbidities associated with CNS & $89(62.2)$ \\
Brain anomaly & $5(3.5)$ \\
ICH & $8(5.6)$ \\
IVH & $22(15.4)$ \\
Meningitis & $11(7.7)$ \\
Seizure/Asphyxia & $43(30.1)$
\end{tabular}

Abbreviations: GA, gestational age; CPS, cardiopulmonary system; $\mathrm{BPD}$, bronchopulmonary dysplasia; CHD, congenital heart disease; PDA, patent ductus arteriosus; CNS, central nerve system; ICH, intracranial hemorrhage; IVH, intraventricular hemorrhage.
전체 18 명(12.6\%)의 환아에서 이상 반응이 있었고 각 이상 반응은 산소포화도의 감소 8 명 $(5.6 \%)$, 심박수의 변화 1 명(0.7\%), 역류증상 7 명 $(4.9 \%)$, 모순적 흥분 1 명 $(0.7 \%)$, 심폐소생술이 필요한 저산소증 을 동반한 심박수 감소 1 명(0.7\%)이었다(Table 2).

출생 시 재태 연령은 이상 반응이 없었던 집단(정상군)보다 이상 반응이 발생한 집단(이상군)이 어렸으나 통계적 의미는 없었다 $\left(37^{+2}\right.$ 주 $\left[32^{+4}-39^{+1}\right]$ vs. $33^{+0}$ 주 $\left[26^{+6}-38^{+0}\right]$, 정상군 vs. 이상군, $\left.P=0.073\right)$. 진정 치료 시행 당시의 교정연령은 정상군보다 이상군에서 어렸고 통계 적 의미의 차이는 없었다 $\left(40^{+1}\right.$ 주 $\left[38^{+2}-41^{+4}\right]$ vs. $37^{+2}$ 주 $\left[36^{+0}-40^{+0}\right], P=$ 0.015).

심폐계의 문제는 두 집단 간에 통계적 의미가 있는 차이가 없 었다 $(P=0.209)$. 정상군은 전체 22명 $(17.6 \%)$ 으로 기관지폐형성이 상 8 명(4.8\%), 선천성심질환 2명(1.6\%), 산소 의존 9명(7.2\%), 치 료가 필요했던 동맥관개존 5명(4.2\%)이었으며 이상군에서는 전 체 6명(33.3\%) 중 기관지폐형성이상 2명(11.1\%), 선천성심질환 0 명 $(0.0 \%)$, 산소 의존 2 명 $(11.1 \%)$, 치료가 필요했던 동맥관개존 2 명 $(11.1 \%)$ 이었다.

중추신경계의 문제는 두 집단 간에 통계적 의미는 없었다 $(P=$ 0.054). 정상군에서 전체 82명(65.6\%)으로 뇌기형 4 명(3.2\%), 두개 강내출혈 8명(6.4\%), 뇌실내출혈 20명(16.0\%), 뇌수막염 11 명(8.8 $\%)$, 경련 및 신생아가사 39명(31.2\%) 이었고 이상군은 전체 7 명 (38.9\%)으로 뇌기형 1 명(5.6\%), 두개강내출혈 0명(0.0\%), 뇌실내출 혈 2명(11.1\%), 뇌수막염 0명(0.0\%), 경련 및 신생아가사 4명(22.2 $\%)$ 이었다.

진정 전처치 시 혈액 검사상 아스파르테이트아미노전달효소, 알 라닌아미노전달효소, 혈액요소질소, 크레아티닌 값은 두 군 간의 차 이가 없었다.

$\mathrm{CH}$ 투여량은 두 군 간의 중간값의 차이 및 통계적인 의미는 없었 으며(50.0 [50.0-50.0] vs. 50.0 [50.0-50.0], $P=0.092$ ) (Table 3), CH 의 2 차 투여는 연구 대상 환아 중 12 명(8.7\%)에서 시행하였다.

다변량 분석 결과 진정 치료 시 $\mathrm{CH}$ 투여 용량만이 통계적으로 유 의하였다(odds ratio [OR], 1.04; 95\% confidence interval [CI], 1.01$1.07 ; P=0.018)$. 그 외 검사 시행 당시의 교정연령 $(\mathrm{OR}, 0.97 ; 95 \% \mathrm{CI}$, $0.95-1.00 ; P=0.053)$, 중추신경계의 문제 $(\mathrm{OR}, 0.37 ; 95 \% \mathrm{CI}, 0.11-$

Table 2. Adverse Events Associated with Chloral Hydrate Sedation

\begin{tabular}{lc}
\hline Adverse events & No. $(\%)$ \\
\hline Desaturation & $8(5.6)$ \\
Heart rates change & $1(0.7)$ \\
Aspiration & $7(4.9)$ \\
Paradoxical agitation & $1(0.7)$ \\
Arrest & $1(0.7)$
\end{tabular}


Table 3. Univariate Analysis for Risk Factors Associated with Adverse Events Using Chloral Hydrate Sedation

\begin{tabular}{|c|c|c|c|}
\hline Variable & Normal group $(n=125)$ & Adverse effects group $(n=18)$ & $P$-value \\
\hline $\mathrm{GA}\left(\mathrm{wk}^{+\mathrm{d}}\right)$ & $37^{+2}\left(32^{+4}-39^{+1}\right)$ & $33^{+0}\left(26^{+6}-38^{+0}\right)$ & 0.073 \\
\hline Corrected age $\left(\mathrm{wk}^{+\mathrm{d}}\right)$ & $40^{+1}\left(38^{+2}-41^{+4}\right)$ & $37^{+2}\left(36^{+0}-40^{+0}\right)$ & 0.015 \\
\hline Morbidities associated with CPS & $22(17.6)$ & $6(33.3)$ & 0.209 \\
\hline $\mathrm{BPD}$ & $6(4.8)$ & $2(11.1)$ & \\
\hline $\mathrm{CHD}$ & $2(1.6)$ & 0 & \\
\hline Oxygen dependency & $9(7.2)$ & $2(11.1)$ & \\
\hline PDA & $5(4.2)$ & $2(11.1)$ & \\
\hline Morbidities associated with CNS & $82(65.6)$ & 7 (38.9) & 0.054 \\
\hline Brain anomaly & $4(3.2)$ & $1(5.6)$ & \\
\hline $\mathrm{ICH}$ & $8(6.4)$ & 0 & \\
\hline IVH & $20(16.0)$ & $2(11.1)$ & \\
\hline Meningitis & $11(8.8)$ & 0 & \\
\hline Seizure/Asphyxia & $39(31.2)$ & $4(22.2)$ & \\
\hline \multicolumn{4}{|l|}{ AST/ALT (U/L) } \\
\hline AST & $30.0(24.0-38.0)$ & $24.5(21.0-39.0)$ & 0.244 \\
\hline ALT & $14.0(10.0-20.0)$ & $14.5(9.0-17.0)$ & 0.922 \\
\hline \multicolumn{4}{|l|}{$\mathrm{BUN} / \mathrm{Cr}(\mathrm{mg} / \mathrm{dL})$} \\
\hline BUN & $7.1(4.2-10.0)$ & $6.3(3.3-11.0)$ & 0.803 \\
\hline $\mathrm{Cr}$ & $0.4(0.3-0.6)$ & $0.3(0.3-0.4)$ & 0.102 \\
\hline Chloral hydrate $(\mathrm{mg} / \mathrm{kg})$ & & & 0.092 \\
\hline Median (range) & $50.0(50.0-50.0)$ & $50.0(50.0-50.0)$ & \\
\hline Mean \pm SD & $53.36 \pm 12.38$ & $60.56 \pm 21.46$ & \\
\hline
\end{tabular}

Values are expressed as median (range) or number (\%) unless otherwise indicated.

Abbreviations: GA, gestational age; CPS, cardiopulmonary system; BPD, bronchopulmonary dysplasia; CHD, chronic heart disease; PDA, patent ductus arteriosus; CNS, central nerve system; ICH, intracranial hemorrhage; IVH, intraventricular hemorrhage; AST, aspartate aminotransferase; ALT, alanine aminotransferase; BUN, blood urea nitrogen; Cr, serum creatinine.

Table 4. Univariate and Multivariate Analyses for Risk Factors Associated with Adverse Events Using Chloral Hydrate Sedation

\begin{tabular}{lcccc}
\hline \multirow{2}{*}{ Predictors } & \multicolumn{2}{c}{ Univariate } & & \multicolumn{2}{c}{ Multivariate } \\
\cline { 2 - 2 } \cline { 5 - 6 } & $P$-value & & $P$-value & OR (95\% CI) \\
\hline Corrected age & 0.015 & & 0.0538 & $0.97(0.95-1.00)$ \\
Morbidities associated with CNS & 0.054 & & 0.0890 & $0.37(0.11-1.14)$ \\
Chloral hydrate dose & 0.092 & & 0.0186 & $1.04(1.01-1.07)$
\end{tabular}

Abbreviations: OR, odds ratio; CI, confidence interval, CNS, central nerve system.

$1.14 ; P=0.089)$ 는 통계적으로 유의하지 않았다(Table 4).

\section{고찰}

$\mathrm{CH}$ 는 신생아를 비롯한 소아의 진정 치료에 널리 사용되는 약물 중 하나로 경구로 투약되며, 투약 후 약물 효과 작용 시간은 15-30 분, 유지 시간은 1-2시간으로 알려져 있다 ${ }^{9)}$. 신생아에서의 $\mathrm{CH}$ 의 약
물 역동학은 명확하지 않지만, 경구로 복용 후 간에서 알코올 탈수소 효소에 의해 활성대사 산물인 삼클로르에탄올로 분해되며 이 물질 에 의해 진정 작용 및 이상 반응이 나타나는 것으로 생각된다. 이후 삼클로르에탄올은 간과 콩팥에서 비활성 대사산물 형태인 삼클로르 아세트산으로 분해되어 소변과 대변을 통해 배출된다. $\mathrm{CH}$ 의 반감기 는 재태 연령 31 주 이상 37 주 미만의 미숙아에서는 $1.01 \pm 0.97$ 시간,

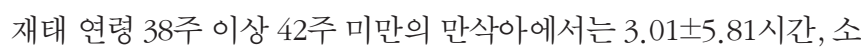
아 및 14 세 미만의 청소년에서는 9.68土7.73시간으로 연령이 증가함 에 따라 반감기가 증가하는 경향이 있으나 활성대사 산물인 삼클로 르에탄올의 경우 미숙아에서 39.82 14.27 시간, 만삭아에서 $27.8 \pm$ 21.32 시간, 소아 및 14 세 미만 청소년에서 9.67士1.72시간으로 미숙 아의 경우 반감기가 더 길게 나타나는 것으로 보고되고 있다 ${ }^{18)}$. 이러 한 이유로 진정효과 및 그에 따른 이상 반응을 일으키는 것으로 생 각되는 삼클로르에탄올이 소아 및 청소년 보다 신생아의 체내에 지 속되는 시간이 길게 유지되어 이상 반응 발생 가능성이 보다 높으며 ${ }^{11,19,20)}$ 진정 치료 후 이상 반응의 발생에 대한 관찰 시간을 길게 유지 할 필요가 있다. 
본원 신생아집중치료실에 입원한 환아 중 자기공명영상 촬영을 위한 경구 $\mathrm{CH}$ 를 이용한 진정 치료를 시행 받은 환아 143 명 중 18 명(12.6\%)에서 이상 반응이 발생하였다. 이 빈도는 Heistein 등 ${ }^{10)}$ 이 보고한 소아에서의 $\mathrm{CH}$ 진정 치료 후의 이상 반응 발생률 $10.8 \%$, Finnemore 등 ${ }^{8}$ 이 보고한 5.1\%보다 높은 발생률을 보였으나 Lee 등 ${ }^{11)}$ 이 보고한 $41.3 \%$ 보다는 낮은 발생률이 확인되었다. $\mathrm{CH}$ 의 진정효 과를 일으키는 물질로 알려진 삼클로르에탄올의 경우 연령에 따라 반감기가 증가하는 경향이 있어 Heistein 등 ${ }^{10)}$ 의 보고에서 대상이 된 환아보다 본 연구의 대상 연령이 낮은점이 이상 반응 발생률의 차이 일 것으로 생각되며 본 연구의 진정 치료 후 시행한 검사인 뇌 자기 공명영상은 상기 보고의 검사인 심장초음파와 비교하였을 때 긴 검 사시간의 필요성 및 필요한 진정 정도의 차이 등에 의한 경구 $\mathrm{CH}$ 추 가 투여 여부의 차이에 의하여 발생률이 보다 높았을 것으로 생각된 다. Finnemore 등 ${ }^{8}$ 의 연구와 비교 시 본 연구에서 모집단의 재태 연 령, 교정연령의 중간값이 더 낮았으며 본 센터와는 다르게 미숙아에 서는 $\mathrm{CH}$ 투여 용량을 $30 \mathrm{mg} / \mathrm{kg}$ 로 시작하는 등의 차이가 있어 이상 반응 발생률 또한 차이가 있었을 것으로 생각된다.

단변량분석의 결과 진정 치료 시행 당시의 교정연령만이 통계 적으로 유의미한 $(P=0.015)$ 요인임으로 나타났으며 심폐계의 문제 $(P=0.209)$, 중추신경계의 문제 $(P=0.054), \mathrm{CH}$ 용량 $(P=0.092)$ 등은 통 계적 유의하지 않았다. 하지만 다변량분석에서는 $\mathrm{CH}$ 용량이 통계 적으로 유의함 $(P=0.018)$ 으로, 진정 치료 당시의 교정연령 $(P=0.053)$, 중추신경계 문제 $(P=0.089)$ 는 통계적 의미가 없음으로 확인되었다.

단변량분석에서만 통계적으로 유의하였던 중추신경계의 문제는 연구집단 전체 143 명 중 89 명에서만 있었고 나머지 환아는 출생 체 중 $1,500 \mathrm{~g}$ 미만 또는 재태 연령 $28^{+0}$ 주 미만이었던 환아를 대상으로 검사 목적으로 진행하였던 경우이다. 연구 결과에서는 재태 연령과 교정연령이 이상 반응 발생에 대하여 통계적으로 유의하지 않았으 나 중추신경계의 문제가 있었던 환아의 경우 경련, 두개강내출혈, 중추신경계 감염 등은 본 센터에서 출생한 환아가 아닌 외부 출생 및 미숙아가 아닌 경우들이 많았고 증상이 있는 급성기가 지나고 생체 징후가 안정된 후 검사를 진행하여 보다 이상 반응이 적었을 것으로 생각된다.

또한 단변량분석에서 통계적 유의하지 않았던 $\mathrm{CH}$ 용량이 이상 반 응이 발생하였던 집단과 발생하지 않았던 집단에서의 중간값이 50 $\mathrm{mg} / \mathrm{kg}$ 으로 같은 값이 나타났으나 두 집단에서의 평균값의 경우 정 상군은 $53.36 \mathrm{mg} / \mathrm{kg}$, 이상군은 $60.56 \mathrm{mg} / \mathrm{kg}$ 이었던 것을 고려하였 을 때 투여된 $\mathrm{CH}$ 용량이 많을 수록 이상 반응의 발생률이 높아지는 경향이 있으나 모집단 전체 수가 적어 단변량분석에서 통계적으로 유의미하지 못한 결과가 도출되었을 것으로 생각된다.

Finnemore 등 ${ }^{8}$ 의 연구에서는 본 연구의 결과와는 다르게 이상 반 응의 발생률이 환아의 출생 재태 연령, 진정 치료 시행 시의 교정연 령, $\mathrm{CH}$ 의 용량 등과 상관관계가 없었다는 보고를 하였다. 위 연구
와 비교 시 본 연구와의 모집단의 연령, 수의 차이, 미숙아에서는 $\mathrm{CH}$ 투여 용량을 $30 \mathrm{mg} / \mathrm{kg}$ 로 시작하는 등의 차이로 이상 반응 발생률 $5.1 \%$ 로 본 연구의 결과와 차이가 발생하였을 것으로 생각된다. 하지 만 Allegaert 등 ${ }^{20}$ 의 연구에서 $\mathrm{CH}$ 투여량이 많을수록 처음 기대하였 던 것보다 긴 진정효과가 지속되었다는 보고 등을 참고할 때 $\mathrm{CH}$ 투 여량의 증가는 이상 반응의 증가로 이어질 수 있다는 내용을 뒷받침 한다.

본 연구는 단일 연구기관에서 시행한 후향적 연구라는 점에서 연 구의 제한점이 있을 수 있으나 진정 지침에 의거,21)하여 시행된 진 정 치료 및 기록된 진정기록을 취합한 데이터로 연구를 시행함으로 써 이러한 제한점을 다소 보완할 수 있었다.

신생아에서 $\mathrm{CH}$ 를 이용한 진정 치료 시행 후 여러 이상 반응이 발 생할 수 있으며 본 연구에서는 통계적인 의미가 없었으나 타 연구들 의 결과에서 이상 반응의 발생률은 연구에 따라 차이가 있지만 진정 치료 시행 당시의 교정연령이 어릴수록 발생률이 증가하는 경향을 확인할 수 있었다. 또한 $\mathrm{CH}$ 투여 용량의 증가에 따라 이상 반응 발생 률이 증가하는 것 또한 확인할 수 있었다.

이상 반응의 발생률은 $12.6 \%$ 로 확인되었고 그 중 심폐소생술이 필요한 저산소증을 동반한 심박수 감소 1 예의 경우 1 회(2분)의 심폐 소생술 시행 후 심박수 60 회/분 이상, 산소포화도 $80 \%$ 이상으로 회 복되어 이후 이에 의한 특이 합병증 없이 퇴원하였던 것 외 치명적인 합병증은 없었다.

이에 신생아의 $\mathrm{CH}$ 진정 치료 시 치명적 이상 반응의 발생은 적으 나타 연령의 소아보다 이상 반응 발생률이 높으므로 진정 치료 후 이상 반응 발생에 대한 관찰을 진정 치료 후 24시간 이상 주의 깊게 해야 할 필요가 있으며 $\mathrm{CH}$ 의 추가 투여를 신중하게 고려해야 한다.

\section{이해관계}

본 저자는 이 논문과 관련된 이해관계가 없음.

\section{REFERENCES}

1. Blencowe H, Cousens S, Oestergaard MZ, Chou D, Moller AB, Narwal R, et al. National, regional, and worldwide estimates of preterm birth rates in the year 2010 with time trends since 1990 for selected countries: a systematic analysis and implications. Lancet 2012;379:2162-72.

2. Doyle LW, Anderson PJ. Adult outcome of extremely preterm infants. Pediatrics 2010;126:342-51.

3. Johnson S, Marlow N. Preterm birth and childhood psychiatric disorders. Pediatr Res 2011;69:11R-8R. 
4. Tocchio S, Kline-Fath B, Kanal E, Schmithorst VJ, Panigrahy A. MRI evaluation and safety in the developing brain. Semin Perinatol 2015;39:73-104.

5. Rose J, Vassar R, Cahill-Rowley K, Stecher Guzman X, Hintz SR, Stevenson DK, et al. Neonatal physiological correlates of nearterm brain development on MRI and DTI in very-low-birthweight preterm infants. Neuroimage Clin 2014;5:169-77.

6. Rutherford M, Srinivasan L, Dyet L, Ward P, Allsop J, Counsell $S$, et al. Magnetic resonance imaging in perinatal brain injury: clinical presentation, lesions and outcome. Pediatr Radiol 2006;36:582-92.

7. Woodward LJ, Anderson PJ, Austin NC, Howard K, Inder TE. Neonatal MRI to predict neurodevelopmental outcomes in preterm infants. N Engl J Med 2006;355:685-94.

8. Finnemore A, Toulmin H, Merchant N, Arichi T, Tusor N, Cox D, et al. Chloral hydrate sedation for magnetic resonance imaging in newborn infants. Paediatr Anaesth 2014;24:190-5.

9. Krauss BS, Krauss BA, Green SM. Procedural sedation and analgesia in children. N Engl J Med 2014;371:91.

10. Heistein LC, Ramaciotti C, Scott WA, Coursey M, Sheeran PW, Lemler MS. Chloral hydrate sedation for pediatric echocardiography: physiologic responses, adverse events, and risk factors. Pediatrics 2006;117:e434-41.

11. Lee J, Youn YA, Kim SJ, Lee HS, Kim SY, Sung IK, et al. Adverse effects of chloral hydrate in neonates: frequency and related factors. J Korean Soc Neonatol 2011;18:130-6.

12. Cote CJ, Wilson S. Guidelines for monitoring and management of pediatric patients before, during, and after sedation for diagnostic and therapeutic procedures: update 2016. Pediatr Dent 2016;38:13-39.

13. Wheeler DS, Jensen RA, Poss WB. A randomized, blinded com- parison of chloral hydrate and midazolam sedation in children undergoing echocardiography. Clin Pediatr 2001;40:381-7.

14. Napoli KL, Ingall CG, Martin GR. Safety and efficacy of chloral hydrate sedation in children undergoing echocardiography. J Pediatr 1996;129:287-91.

15. Litman RS, Soin K, Salam A. Chloral hydrate sedation in term and preterm infants: an analysis of efficacy and complications. Anesth Analg 2010;110:739-46.

16. Gilstrap LC 3rd, Leveno KJ, Burris J, Williams ML, Little BB. Diagnosis of birth asphyxia on the basis of fetal $\mathrm{pH}$, Apgar score, and newborn cerebral dysfunction. Am J Obstet Gynecol 1989; 161:825-30.

17. Executive summary: neonatal encephalopathy and neurologic outcome, second edition. Report of the American College of Obstetricians and Gynecologists' Task Force on Neonatal Encephalopathy. Obstet Gynecol 2014;123:896-901.

18. Mayers DJ, Hindmarsh KW, Sankaran K, Gorecki DK, Kasian GF. Chloral hydrate disposition following single-dose administration to critically ill neonates and children. Dev Pharmacol Ther 1991;16:71-7.

19. Malviya S, Voepel-Lewis T, Tait AR. Adverse events and risk factors associated with the sedation of children by nonanesthesiologists. Anesth Analg 1997;85:1207-13. Erratum in: Anesth Analg 1998;86:227.

20. Allegaert K, Daniels H, Naulaers G, Tibboel D, Devlieger H. Pharmacodynamics of chloral hydrate in former preterm infants. Eur J Pediatr 2005;164:403-7.

21. Sury M, Bullock I, Rabar S, Demott K; Guideline Development Group. Sedation for diagnostic and therapeutic procedures in children and young people: summary of NICE guidance. BMJ 2010;341:c6819. 